Article

\title{
Comparison of Weak and Strong Theories of Environmental Sustainability in the Conceptual Context of Sustainable Devel- opment
}

\author{
Nima Norouzi ${ }^{\circledR}$, Maryam Fani * \\ Department of Energy Engineering and Physics, Amirkabir University of Technology (Tehran Polytechnic), \\ 424 Hafez Avenue, PO. Box 15875-4413, Tehran, Iran \\ *Correspondence: mfani@aut.ac.ir;
}

How to cite this paper : Norouzi, N., \& Fani, M. (2021). Comparison of Weak and Strong Theories of Environmental Sustainability in the Conceptual Context of Sustainable Development. Research Journal of Ecology and Environmental Sciences, 1(2), 108-122. Retrieved from https://www.scipublications.com/journal/index.php/rjees/article/view/144

\begin{abstract}
Ever since the idea of sustainable development was proposed, how to achieve it has always been the focus of researchers and policymakers. At the same time, in the letters of sustainable development, two approaches of weak sustainability and strong sustainability have been mentioned; Two approaches with different assumptions suggest different policies and will have different consequences. On the other hand, with the increase of environmental concerns in recent decades, the concept of natural capital and physical, human, and social capital has been added to the common literature of economics. Recently, with the collection of data related to the natural capital of nations by the World Bank, the possibility of statistical studies in this field has been provided. In the form of several regression models and at the international level, the present study will analyze the most fundamental difference between the two approaches of weak sustainability and strong sustainability, i.e., the possibility or impossibility of replacing physical capital instead of natural capital. The study results show that natural capital has a direct, positive, and independent role in explaining sustainable development indicators. Even the addition of physical, human, and social capital indicators does not threaten the significant coefficient of natural capital. Therefore, it can be concluded that under the assumption of a strong sustainability model, other types of capital can not replace natural capital.
\end{abstract}

Keywords: Natural capital, sustainable development, environmental footprint, biological capacity, human development index, Ecological Economy, Sustainable Economy.

Received: August 26, 2021

Accepted: October 6, 2021

Published: October 7, 2021

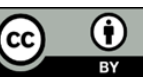

Copyright: (C) 2021 by the authors. Submitted for possible open access publication under the Creative Commons Attribution (CC BY) license

(http://creativecommons.org/licenses /by/4.0/).

\section{Introduction}

All believe development to be a desirable phenomenon because, by definition, it will bring a better future, past, and present. But the model of achieving this goal as an influential issue in how society's resources are allocated has always been of interest to economists[1]. One of the most important issues for policymakers is explaining and regulating the relationship between development, capital, and natural resources. On the one hand, nature consumes the energy and resources necessary for production, and as a result, provides utility, and on the other hand, by absorbing, refining, or storing pollutants and leaving no traces of pollutants and wastes. Although some policymakers may still have this view of nature, there have been dramatic developments in the field since the idea of growth constraints $[2,3]$.

The designers of the idea of growth constraints believed that the existing process of economic growth would lead to widespread degeneration and stalemate; Efforts to respond to this idea, as well as to raise environmental issues, have led economists to develop concepts that today make up a significant portion of research related to the growth and development of the economy[4]. It specializes. Sustainable development is one of the most 
influential concepts presented in this period. Sustainable development is a normative concept that deals with the preservation and survival of integrity in the economic system and refers to establishing a kind of balance between economic, social, and environmental goals (2000). From this point of view, economists today are paying more and more attention to the two-way effect of the natural capacities of the environment and the process of economic development so that nature, along with other types of capital, becomes a source of capital. Sustainable development, in which the four types of capital - physical capital (the sum of financial and productive capital (human, natural, and social - capital) - are not known to the economy and are as important to the economy. Goods and services result $[5$, 6].

Over time, researchers' efforts to develop the concept of sustainability and apply it to policy-making have led to two competing perspectives in this area: two perspectives known for poor sustainability and strong sustainability. Simply put, some experts believe in the possibility of substituting different types of capital and see the sustainability of a set of capitals as the goal of sustainable development (poor sustainability), while others do not[7]. The accumulation of natural capital - independent of other types of capital alone must be stable over time (strong sustainability). There is no doubt that the acceptance of either of these two perspectives will have completely different policy implications in production, society, and the environment, but this article is more than a theoretical or theoretical study[8]. To analyze the political consequences of theories and their results, it is to explain the role and contribution of natural capital and social capital in the process with an empirical approach and with the help of econometric tools. Of course, it should be noted that the results of this study can be a basis for choosing between two competing theories of strong or weak sustainability. This study will examine the extent to which natural capital per capita can explain the differences in the indicators related to sustainability in different countries[9]. The answer to this question can be a criterion for assessing the importance that nations attach to their per capita natural capital; According to the results of this study, it can be examined whether the awareness of communities has reached a point where they prefer the growth of natural capital to the growth of national income in comparison[10].

In the field of experimental studies, one of the most important concerns of the researcher is the measurement of each variable. Which indicators are appropriate and efficient for measuring sustainability, physical capital, natural capital, or social capital, is a broad and controversial issue. This article will try to use a relatively comprehensive set of indicators used and valid to measure each of these variables, based on various previous studies[11].

In this study, cross-sectional data related to the year 2020 for 59 countries of the world have been used. In the continuation of the article, first, some previous studies in this field will be reviewed. After referring to the theoretical foundations in the third section, in the fourth section in two parts, first, the definitions and how to collect data and then the results of econometric models are presented, and finally, in the final section of the article, summary and conclusion is mentioned.

\section{Literature review}

Literature and research in this field can be divided into two categories: First, the group of theoretical studies that have developed in developing the concept of natural capital and the need to pay attention to it in models of sustainable development. One of these is ref. [12]. While rereading the theoretical foundations of social capital and designing human interaction with nature on the path to sustainable development, he addresses some of the challenges facing nature as capital. Explains and discusses the economic value of natural resources and their role in maintaining the development process; And based on the theory of desirability, they examine how to make the best use of natural capital. But 
the second group are relatively numerous studies that have been done for practical purposes. In most of these studies - of course, by defining different measurement tools - the relationship between natural capital and one of the indicators of sustainable development (for example, happiness index) have been studied. Then the researcher has used the estimation model by using the estimation model. For example, A study[13] examined the relationship between natural capital and quality of life. They directly divide the lives of individuals (indirectly) and indirectly (provide resources for production) and, relying on this conceptual framework, identify possible paths for sustainable development by comparing different paths. Another study[14] also uses the investment criterion, which is quite common in the physical capital literature, to present a new method for measuring natural capital, and using the same method, according to the cost of government, The amount of investment in the field of natural capital b Calculates the vote for the fiscal year 2004-2015.

Nevertheless, a study[15] may be considered the first study to examine the relationship between happiness and the environmental conditions of countries at the international level. However, it has followed the same approach in two other studies and used how people's life satisfaction changes with the change of two variables of income and environmental quality; this study has thus succeeded in not only calculating the optimal rate of preventive measures to reduce the volume of pollutants, but also the monetary value of this improvement. In addition, it emphasizes the satisfaction index (as a multidimensional indicator for measuring happiness), indicating that the index has a high capacity for use in environmental analysis and is not. The basis of this index is the calculation of monetary value that improves the quality of the environment.

Another research [16] has been one of the main role models in shaping this article. Their study examined the effect of physical, natural, human, and social capital on explaining the life satisfaction index in 170 countries. Of course, this research has some shortcomings and has been criticized in other articles such as ref. [17-20]. The main shortcomings of this article can be categorized into three groups: First. The study of ecosystem value index per square meter has been used to measure natural capital, an index that researchers do not agree on its comprehensiveness and efficiency. And have used the Human Development Index as a tool for both human and physical capital, and finally, the data used in this paper are relatively old and, in addition, for countries with different data years. However, their econometric model has yielded significant results. Based on their findings, the end of the article proposes a new indicator for measuring sustainability called the National Happiness Index, although we seek to compare the two competing perspectives empirically.

However, comparing the two concepts of strong sustainability and weak sustainability in the form of empirical models, as the main goal of the present article, is also one of the new topics in the field of environmental economics. Coherence and comprehensive in this regard have not been done. Of course, such issues seem quite justifiable given the notso-long history of data collection on sustainable development indicators and the lack of methodological unity in how these indicators are calculated. Other studies like [21, 22] can be included in this study with a little tolerance. After analyzing and comparing the political concepts and consequences of each of the two competing points of view, this article introduces its proposed indicators for measuring these two points of view. After listing these characteristics' characteristics, it presents its competing two points of view for measuring the two competing points of view.

Also, a study in recent years[23] as one of the latest research in the field uses an intermediate approach, instead of rejecting or accepting one of the two competing views, by attempting to establish a common discourse between the two theories called sustainable developmental reflection to establish a kind of prophecy between these two theories. Nielsen bases his study on the assumption, albeit seemingly correct that proponents of the two concepts of weak and strong sustainability not only have a completely different interpre- 
tation of emotion but also consider the other side's view to be irrational and invalid; However, by introducing weak sustainability as an appropriate description of the current state of the world and proposing strong sustainability as the normative target for environmental policies, he tries to emphasize the rule of law by emphasizing the rule of law. Proposals based on these two perspectives can be complementary rather than competing.

\section{Theories and framework}

This section of the article pursues two goals; At first, definitions are presented as accurately as possible from the two competing perspectives under consideration, namely weak sustainability, and strong sustainability, and then after a detailed review of the definitions.

Sustainable development, concepts, theoretical foundations, and characteristics of non-measurement of sustainability and different types of capital in the economy will be discussed. As noted, sustainable development provides a good platform for study by nature, social welfare, and holistic development. The concept of sustainable development was met with widespread acclaim by researchers and even policymakers, but in practice, there were differing and sometimes contradictory views on this issue, which ultimately led to the two perspectives of weak sustainability and sustainability.

Poor sustainability is a condition for the survival and sustainability of total capital value (including physical capital, social assets, and natural endowments). According to this theory, the very weak state of which is called solo sustainability by one of the most famous theorists of economic growth (solo), it is sufficient for the general capacity of production to remain constant over time in such a way that it is consumed domestically[23]. Despite the adjustments made, in general, poor sustainability addresses the sustainability of the economic capital complex, and in a sense, it can be argued that proponents of this theory substitute different types of capital for each other[24]. In poor sustainability, neither nature nor other types of capital have any intrinsic value and are only tools to reach the highest possible level of desirability.

Calculating the compensatory values is one of the biggest shortcomings of this theory, that is, answering how much capital should be replaced to compensate for the destruction of an ecosystem. In addition, even the proponents of weak sustainability theory have debated the assumption of capital substitution. Some have challenged the assumption of indefinite substitution, while others have argued for practical barriers to the replacement of physical capital with natural capital [22].

On the other hand, strong sustainability, relying on the role of nature, emphasizes that - at least some -

Environmental characteristics must remain stable over time [23]. Capital is considered to be very low and close to zero instead of natural capital. This approach can be considered equivalent to the sustainability of natural capital overtime on the sustainability of natural resources. They consider each other that both must remain stable at the same time.

The fact is that in today's world, economic and environmental policies are more likely to be designed and implemented in the context of the concept of weak sustainable development. Environmental Economics If it wants to introduce its proposed alternative as a basis for future policy-making, it must simultaneously take at least three different paths: first and foremost, its political implication; The present study can be the beginning of a step in this direction[23, 24].

Before examining econometric patterns, it is worthwhile to briefly examine the capitalist approach to explaining sustainable development, the different types of capital, and their measurement indicators. The United Nations [25] considers sustainable development to be a development in which "by replacing or conserving the main sources of wealth, namely the volume of productive, human, social and natural capital, the non-declining path of national wealth in the country. " This definition, which is based on the 
capitalist view of economic development, can provide a good basis for the present research because it goes beyond classical theories of the physical and material views. Although development is traditionally measured only by increased per capita income or GDP, researchers in various fields have sought to add new components, such as environmental damage, education, and health. Today, they use them as a combination of indicators. The United Nations report identifies the happiness index as an appropriate indicator of this goal, and even beyond that, it defines development as "increasing the well-being of members of society over time" [26]. P.44 introduces the Happiness Index as "a solid foundation for measuring sustainable development." Similar views can be found on pages 3,2 , and 19 of this report. Sustainable development encompasses diverse economic, social, and environmental aspects, and finally, research [27] has used the same indicator to measure sustainability in their studies. For this reason, in this study, the happiness index has been considered the main indicator for measuring sustainable development; in addition to this index, two indicators of life satisfaction and the happy planet index have also been used as indicators for happiness.

The dependent variable indices to measure sustainable development will include econometric models in this paper. In rows, explanatory variables will be tried according to previous studies, instruments to measure different species of capital (physical, human, natural, and social) must be provided. In this way, it is possible to evaluate and compare the share of each of them in the happiness index.

The first type of capital, namely physical capital, has long been considered the main component of development in the economic literature. Due to the richness of the writings and to avoid explaining the details, the concept of physical capital is not addressed. In this study, two per capita GDP and per capita national income indicators have been used to measure per capita physical capital. It should be noted that in addition to these two indicators, in the literature [26-33]; two variables of the unemployment rate and inflation rate as important variables in explaining. These two variables, although they may not be a direct indicator for measuring physical capital, can certainly not be considered in addition to the general characteristics of income in general. On the one hand, almost all related studies have used GDP per capita or national income indicators to explain the happiness index or other similar indicators. They are considered constants, and their omission from the pattern leads to biasing of the estimated coefficients. On the other hand, a review of previous studies shows that physicians are more important than others. And Vemuri \& Costanza Development Index considered human beings as the basis for measuring physical capital. In addition, physical capital is affected by the increase in the value of fixed assets (both land and inventory) and the amount of investment in the economy. Since, according to macroeconomic theories, these variables themselves are affected by changes in production or income, as well as inflation and unemployment in the economy, a set of these indicators can be considered a suitable combination for measuring physical capital. For this reason, in this study, the same indicators have been used to measure physical capital. The second type of capital that plays a pivotal role in this study is natural capital. The idea of natural capital is not so new, but similar views can be found in the writings of economists such as Malthus, Ricardo, and even some neoclassical economists. However, the emergence of an independent field called environmental economics has led to a greater emphasis on the role of natural capital in the discourse of human well-being and happiness (Natural income) will follow goods and services [34, 35]. Natural capital can be divided into renewable and non-renewable hands. Fossils have very low reproduction rates, so that they can only be imagined once at a time. According to ref. [36], sustainable development is economic growth as long as the accumulation of natural capital remains stable. Equal to shocks, It should also be considered external.

Natural capital combines the three components of land, natural resources (renewable and non-renewable), and ecosystems. Still, the valuation and measurement of environmental goods and services do not face many difficulties. For this reason, the measurement 
of natural capital follows complex patterns, which we do not intend to address at this time. This study uses two alternative indicators to measure the per capita natural capital of countries. The first indicator is the headline of natural capital based on the statistics presented in the World Bank report [36, 37]. This report can also consider the difference in environmental footprint and per capita biological capacity in each country as a tool for measuring natural capital, although I have not used such an indicator for measuring natural capital before. There are no studies - but their meaning may be the reason for these authors' suggestions, which we will cover in more detail in the next section of this article.

The third type of capital is social capital. Among the types of capital, social capital is the latest type, and therefore, as the United Nations report [33] points out, among the types mentioned above of capital, it has been studied less than others. The same report of social capital as the characteristics of social organizations such as the level of trust, norms, and networks (civic interaction) that improve the efficiency of society by facilitating coordinated actions or institutions, relationships, and norms that improve the quality and quantity of interactions. Despite the existing complexities and the nascent literature on the subject, methods for measuring social capital have been introduced in recent years. Some researchers have introduced the trust index, some have introduced the average membership of individuals in voluntary organizations, and some have introduced a combination of them to measure social capital. However, for measuring social capital, there are still no common methods accepted by most researchers, and this issue is also considered a topic worthy of further discussion. However, in terms of the role of social capital in sustainable development, various studies have been conducted on the consequences of social capital growth in economics. For a new research sample [34], the economic effects of the growth of social capital and another [35] study on the relationship between the growth of social capital and the happiness index have been studied. Based on the studies, social capital has been accepted as one of the most important components affecting life satisfaction. Although this indicator is less important in developing countries, it can affect people's life satisfaction even more than income issues or income inequalities in rich countries. This study uses three valid factors to measure social capital; first, the Gini coefficient, which shows income inequalities in each society. This character has also been used in Engelbert. According to previous studies, this indicator is expected to be a suitable symbol of social capital, especially in less developed countries. In addition to the Human Development Index and one of its main components, life expectancy has been used as two other tools to measure social capital. Because this index, as one of the most widely used compositional characteristics in society, deals with various aspects, including educational and health issues. In addition, this index can be considered as a tool for measuring human capital. However, in other studies, characteristics such as the public confidence index have been considered that have not been used in this study due to lack of access to relevant data [35-41].

Finally, it must be said about human capital that although it does not yet have a single and specific definition, everyone has accepted that the quality and capacity of human resources affect the well-being of the economy. A winner of the Nobel Prize in Economics in 1992, he was one of the first designers of the term human capital, for which he listed the three components of education, on-the-job training, and health [41]. In the present study, the education index has been used to measure natural capital. Considering the presence of the human development index for measuring social capital, it is expected that the simultaneous presence of two indicators of education and human development in the models is a suitable tool for measuring human capital; A similar approach has been used in the study [42].

\section{Materials and Methods}


In this section, while briefly introducing the variables used in econometric models, we discuss how to collect and explore them. In the following, we will estimate the coefficients of the patterns and analyze the results by introducing alternative models.

Index of happiness. This index is extracted based on the polls of the World Values Survey Center. The happiness index is a combination calculated from the difference between the two indices of life satisfaction (LS) and satisfaction. These two indicators are determined as a result of direct questions from the audience. The Global Values Survey Center questionnaires are regularly distributed around the world in different periods, and the results of the surveys are also provided to the researchers through the website of this center. The data used in this article are related to (for some countries, due to lack of data, the closest year to 2020)[44].

Two indicators of happiness (HPI) and LS (life satisfaction) have been used as alternatives to happiness. According to the collectors of the Happy Planet Index, the purpose of its design was to measure happiness, and for this reason, it has been taken as a substitute for happiness. Happiness car is a combination of economic, political, social, and environmental variables, and in addition, the third alternative is the use of the life satisfaction index (LS), which is one of the most important components in the index. It is a measure of happiness, and for this reason, it has also been considered separately as an alternative, and life satisfaction index data have also been extracted from the (un) happy planet index report.

Physical capital. Two indicators of per capita GDP and per capita national income were used to measure physical capital. Relevant data are taken from the World Bank data set[45]. Of course, the capital formation index can also be used to measure physical capital, but in most articles in this field, income indicators are considered a symbol of physical growth and growth as a symbol of growth. Explanations have been used in the models for measuring sustainable development, and they have been sufficient in this article.

Natural capital is one of the most important components of a nation's wealth. According to the World Bank, "Where is the Wealth of Nations?", Natural capital in highincome countries accounts for $2 \%$, in middle-income countries about $13 \%$, and in lowincome countries $26 \%$ of each country's wealth. The data in this article are taken from the first appendix of the World Bank report. In addition, the per capita difference between ecological footprint and biological capacity has been used as an alternative. Although even in many studies, to measure the quality of the environment, only data related to one or more pollutants are sufficient, but the increasing scope of environmental studies requires the introduction of a comprehensive index that represents the status of a variable The environment as a whole has become more apparent[32].

Table 1. Descriptive statistics of the studied variables

\begin{tabular}{cccccccc}
\hline Parameter & $\begin{array}{c}\text { Kurto- } \\
\text { sis }\end{array}$ & $\begin{array}{c}\text { skew- } \\
\text { ness }\end{array}$ & $\begin{array}{c}\text { Std. } \\
\text { Dev. }\end{array}$ & Min & Max & Mean & Unit \\
\hline Happiness index & 2.31 & -0.55 & 1.13 & -2.5 & 4.45 & 1.89 & - \\
Happy Planet Index & 3.00 & -0.08 & 10.22 & 16.9 & 67.90 & 42.90 & - \\
Life Satisfaction Index & 2.51 & -0.53 & 1.28 & 3.4 & 8.22 & 6.10 & - \\
GDP per capita & 2.33 & 0.64 & 11479.21 & 1104.70 & 48915.91 & 14478.90 & USD,2000 \\
GNP per capita & 2.47 & 0.86 & 11470.18 & 598.90 & 38975.40 & 11328.22 & USD,2000 \\
Natural capital per capita & 11.66 & 2.88 & 10245.90 & 0.00 & 54829.98 & 7905.12 & USD,2000 \\
Per capita environmental foot- & 2.28 & 0.44 & 2.22 & 0.66 & 9.60 & 3.66 & Global acres \\
$\quad$ print & & & & & & & Global acres \\
Biocapacity per capita & 13.43 & 2.93 & 3.67 & 0.18 & 22.88 & 3.12 & - \\
Human Development Index & 6.28 & -1.56 & 0.16 & 0.20 & 0.96 & 0.81 & - \\
$\quad$ Education Index & 5.31 & -1.72 & 0.11 & 0.73 & 1.02 & 0.88 & - \\
\hline
\end{tabular}




\begin{tabular}{|c|c|c|c|c|c|c|c|}
\hline Gini coefficient & 2.89 & 0.67 & 9.23 & 24.33 & 59.29 & 38.22 & $\%$ \\
\hline Inflation rate & 12.22 & 3.05 & 11.71 & 35.12 & 55.18 & 43.12 & $\%$ \\
\hline Unemployment rate & 4.51 & 1.22 & 4.12 & 7.8 & 27.3 & 17.24 & $\%$ \\
\hline
\end{tabular}

The environmental footprint index is the most important and widely used indicator that has been proposed in this field to date[46]. The environmental footprint states at what rate each country's nature must reproduce itself to maintain the pattern of resource extraction, production, consumption, and pollution. For example, if the fishing rate in the Caspian Sea is $x$ units per year, the fish in the Caspian Sea must be produced at a rate equivalent to $x$ units per year to maintain this pattern of harvesting in the long run. Environmental footprint tries to provide a single number of the environmental system of each country by combining all perceptions, consumptions, and pollutants. On the other hand, bio-capacity shows at what rate the nature of each country can reproduce itself. If the fish of the Caspian Sea are reproduced at a rate of one unit per year, a comparison of $\mathrm{x}$ and $\mathrm{y}$ can map the future of the fish of this sea[47].

The beginning of the calculation and collection of data related to these two variables does not take long, and the data related to them are available to researchers only for a few years. The information used in this article is extracted from the report of the car in life in 2018 and 2020, which published the information for 2016 and 2017. Given that the other report data are related to the year 2020, the average data of these two years are included as values related to the environmental footprint and bio-capacity in the year 2020. In addition, the two variables in question do not change much over short periods; A comparison of data for the years 2016 and 2020 illustrates this well[48, 49].

Indicators of human development and education. Data from these two individuals have been extracted from United Nations reports under the title Human Development Report[50].

Gini coefficient. The Gini coefficient is an indicator that shows the level of income inequalities in each country. Information related to this variable has been extracted from the set of world development indicators; Because for some countries, the information of the year closest to 2020 has been used[51].

Inflation rate and unemployment rate. Information related to these two variables has also been extracted from the set of world development indicators.

\section{Results}

As noted in the previous sections of this article, what is most important in analyzing the two theories of strong and weak sustainability by environmental economists is the substitution of physical capital for natural capital. To this end, we begin by examining the share of natural capital in sustainability indicators. Table 2 is the estimates related to the three models in which the characteristics of happiness, happiness, and life satisfaction are regulated on the natural resources of the regression (the pattern is exaggerated). Except for the third model in which the happiness index is used, the coefficient of natural capital is statistically significant in the other two models, and its sign is consistent with the theoretical expectations.

$$
S I=\beta_{0}+\beta_{1} N C+\varepsilon
$$

In other words, if we consider happiness or life satisfaction as an indicator of sustainability, natural capital will play a significant role in explaining sustainability.

Table 2. The share of natural capital in explaining the sustainability indicators

\begin{tabular}{clcc}
\hline & Welfare & Life satisfaction & Happiness \\
\hline Y-intercept & $55.44(12.47)$ & $1.12(0.98)$ & $-5.26(1.89)$ \\
\hline
\end{tabular}




\begin{tabular}{|c|c|c|c|}
\hline $\begin{array}{c}\text { Natural capital per cap- } \\
\text { ita }\end{array}$ & $-1.48(1.45)$ & $0.60(0.12)$ & $0.92(0.22)$ \\
\hline $\mathrm{R}^{2}$ & 0.18 & 0.24 & 0.19 \\
\hline Durbin-Watson & 1.92 & 1.94 & 1.91 \\
\hline
\end{tabular}

Now, to examine the possibility of substitution of physical and natural capital, we estimate the patterns in the row of dependent variables, one of the three alternatives presented as an indicator of SI sustainability, the characteristics of happiness, happiness, and happiness in happiness and happiness in happiness. Physical PCs and NC Alternative Capital Features. Equation (2) shows the general form of the estimated pattern[52]:

$$
S I=\beta_{0}+\beta_{1} P C+\beta_{2} N C+\varepsilon
$$

Considering all possible substitutions, it is possible to estimate 12 different patterns, of which the top five patterns are reported in Table 3. Heterogeneity is a common phenomenon. The standard deviation of the coefficients of all patterns is reported after eliminating variance[53-60]. Heterogeneity is observed. Explanatory, it seems perfectly acceptable. With the introduction of physical capital into the model variables, the power of explanation has increased significantly from about $20 \%$ to more than $50 \%$. This fact suggests the undeniable role of income in explaining sustainability indicators.

Nevertheless, despite the existence of physical capital, except for the fourth model, in all models, the coefficient of natural capital has been estimated to be statistically significant and opposite to zero. Therefore, relying on the assumptions made, one can challenge the assumption of a weak sustainability theory based on replacing physical capital with natural capital. Finally, it should be noted that the introduction of the marginal difference in biological capacity and environmental footprint, as indicators for measuring natural capital in the form of sustainable development models, has not been discussed in previous studies. The results of Table 3 show that four of the top five models have used the same indicator to measure the environment. This can be a confirmation of the researchers' assumption in defining this index[61].

Table 3. Estimation of patterns involving both physical and natural capital

\begin{tabular}{|c|c|c|c|c|c|}
\hline & $\begin{array}{c}\text { Life satis- } \\
\text { faction }\end{array}$ & $\begin{array}{l}\text { Life satis- } \\
\text { faction }\end{array}$ & $\begin{array}{l}\text { Life satis- } \\
\text { faction }\end{array}$ & $\begin{array}{l}\text { Happi- } \\
\text { ness }\end{array}$ & $\begin{array}{l}\text { Happi- } \\
\text { ness }\end{array}$ \\
\hline Y-intercept & $5.11(0.18)$ & $4.17(1.12)$ & $4.13(0.41)$ & $0.44(0.27)$ & $\begin{array}{l}-0.82 \\
(0.66)\end{array}$ \\
\hline GDP per capita & - & - & $0.89(0.12)$ & - & $1.17(0.24)$ \\
\hline Per capita national income & $0.66(0.09)$ & $0.61(0.11)$ & - & $0.82(0.09)$ & - \\
\hline Natural capital per capita & - & $0.17(0.11)$ & - & - & - \\
\hline $\begin{array}{l}\text { Per capita difference between ecologi- } \\
\text { cal footprint and biological capacity }\end{array}$ & $0.08(0.05)$ & - & $0.06(0.02)$ & $0.09(0.05)$ & $0.08(0.02)$ \\
\hline $\mathrm{R}^{2}$ & 0.62 & 0.58 & 0.54 & 0.53 & 0.42 \\
\hline Durbine-Watson & 1.69 & 1.75 & 1.71 & 1.88 & 1.79 \\
\hline
\end{tabular}

We now turn to patterns in which all four types of physical, natural, human, and social capital are considered. Equation (3) shows the general form of these patterns.

$$
S I=\beta_{0}+\beta_{1} P C+\beta_{2} N C+\beta_{3} H C+\beta_{4} S C+\varepsilon
$$

Three indicators of happiness, happiness and life satisfaction have been used to measure SI sustainability in these models. To measure the physical capital of PC, two alternatives of per capita income and GDP per capita were used to measure the natural capital index of NC. We used two alternatives of natural capital per capita and the difference between ecological footprint and biological capacity. The human development index, 
education index, and Gini coefficient have also been considered measuring human and social capital. Of course, all the models in the absence of the education index have also been estimated due to the possibility of overlap between the education index and the human development index. In addition, two variables of the unemployment rate and inflation rate are also included in the models. These features have always been the focus of researchers in similar studies in the past, including [41-52].

Table 4. Estimation of patterns involving all types of capital.

\begin{tabular}{ccccc}
\hline & Life satisfaction & Happiness & Happiness & Happiness \\
\hline Y-intercept & $2.01(1.22)$ & $0.44(2.02)$ & $-0.18(2.35)$ & $-4.81(1.92)$ \\
GDP per capita & $0.52(0.31)$ & - & - & $0.96(0.33)$ \\
Per capita national income & - & $1.17(0.19)$ & $1.17(0.26)$ & - \\
Natural capital per capita & $0.28(0.18)$ & - & - & $0.41(0.32)$ \\
Per capita difference between ecolog- & - & $0.09(0.02)$ & $0.05(0.02)$ & - \\
ical footprint and biological capacity & - & $0.81(2.67)$ & $-2.44(3.05)$ & $3.62(2.57)$ \\
Human Development Index & $1.12(1.55)$ & $-4.02(1.62)$ & - & $-4.31(1.23)$ \\
Education Index & - & $0.11(0.02)$ & $0.08(0.02)$ & $0.07(0.03)$ \\
Gini coefficient & $0.05(0.02)$ & $-0.05(0.02)$ & $-0.05(0.02)$ & $-0.04(0.02)$ \\
The inflation rate & $-0.03(0.01)$ & $-0.04(0.03)$ & $-0.03(0.02)$ & $-0.06(0.01)$ \\
Unemployment rate & $-0.05(0.03)$ & 0.69 & 0.66 & 0.59 \\
$R^{2}$ & 0.64 & 1.75 & 1.78 & 1.62 \\
Durbin-Watson & 1.81 & & &
\end{tabular}

Thus, and taking into account all possible permutations, there were a total of 24 predictable models, with estimates for the eight selected models in Table 4. The selection of superior models has been done according to the degree of explanatory nature of the model, the significance of the whole model, and the significance of the coefficients. Increasing the model's explanatory power was an expected phenomenon due to the increase in the number of explanatory variables, but according to the obtained results, it is necessary to point out a few points[62-67]. Adding an education index to patterns and increasing the explanatory power of the pattern also helps to make the pattern coefficients more meaningful. This can be well understood by comparing the fifth and sixth columns and the seventh and eighth columns. Since the addition of this variable is also discussed for the first time in this study, the obtained results can be considered assumptions of researchers. In addition, the coefficient of the education index in all models is estimated to be negative. It can be justified that with the increase of education in the society, the level of expectations and demands of the society increases, and as a result, more attention is paid to the shortcomings and unstable factors of the development process. For this reason, if the level of education in the society improves, assuming the sustainability of other conditions, the society will consider the previous situation more unstable[68]. 
Table 5. Estimation of patterns involving all types of capital

\begin{tabular}{ccccc}
\hline & $\begin{array}{c}\text { Life satisfac- } \\
\text { tion }\end{array}$ & $\begin{array}{c}\text { Life satis- } \\
\text { faction }\end{array}$ & $\begin{array}{c}\text { Life satis- } \\
\text { faction }\end{array}$ & $\begin{array}{c}\text { Life satisfac- } \\
\text { tion }\end{array}$ \\
\hline Y-intercept & $3.58(1.32)$ & $5.07(1.24)$ & $4.75(1.26)$ & $2.24(1.22)$ \\
GDP per capita & - & - & - & $0.55(0.21)$ \\
Per capita national income & $0.55(0.15)$ & $0.61(0.14)$ & $0.66(0.16)$ & - \\
Natural capital per capita & $0.33(0.13)$ & - & - & $0.29(0.14)$ \\
Difference between environmental footprint & & $0.08(0.02)$ & $0.05(0.01)$ & - \\
and biocapacity & - & & \\
Human Development Index & $1.67(1.33)$ & $2.11(1.12)$ & $0.028(1.59)$ & $2.79(1.33)$ \\
Education Index & $-2.33(1.15)$ & $-2.31(1.17)$ & - & $-2.55(1.18)$ \\
Gini coefficient & $0.03(0.01)$ & $0.05(0.02)$ & $0.03(0.01)$ & $0.02(0.01)$ \\
The inflation rate & $-0.02(0.01)$ & $-0.02(0.01)$ & $-0.04(0.01)$ & $-0.02(0.01)$ \\
Unemployment rate & $-0.04(0.02)$ & $-0.03(0.02)$ & $-0.03(0.01)$ & $-0.05(0.01)$ \\
R & 0.71 & 0.69 & 0.65 & 0.68 \\
Durbin-Watson & 1.85 & 1.67 & 1.70 & 1.73 \\
\hline
\end{tabular}

As expected, a positive sign for the physical and natural capital coefficients indicates that an increase in income or an improvement in environmental conditions indicates greater sustainability of the development process. Regarding other variables, it should also be said that although no meaningful estimates have been obtained for them in some models, the sign of the coefficients is following the theoretical expectation, and due to their distance from the object of study, it has been studied. Examining the coefficients of natural capital and their standard deviation in the patterns in Tables (4 and 5) shows that physical, human, and social capital is not a factor in removing natural capital from econometric models[69]. In other words, it can be claimed that the experimental results of this study confirm strong environmental sustainability. This means that increasing physical capital cannot be a substitute for natural capital in the process of sustainable development[70]. Natural capital, as evidenced by the estimation of econometric models, plays a positive and independent role in explaining the characteristics of sustainable development. Therefore, if policymakers and researchers seek to propose and implement sustainable development policies, they should be aware that, contrary to popular belief, the destruction of the environment can not be achieved by the growth of any other species. Road construction, expansion of industries, and other development policies, if they are done at the cost of destroying forests, lakes, and the environment in general, which will not guarantee the sustainability of the development process, why none of the types of capital can replace the natural capital[71-73].

\section{Conclusions}

While reviewing the literature on sustainability and comparing the two perspectives of strong sustainability and weak sustainability, this article, using econometric models, has evaluated the degree to which the claims of the two perspectives of strong and weak sustainability are in line with real data. For this purpose, 36 patterns were estimated, of which the best patterns are reported in the text of the article. The choice of superior patterns has been due to the explanatory power of the patterns and the significance of the coefficients. The results show that natural capital alone can explain about $20 \%$ of the changes in sustainable development indicators. In addition, natural capital still retained 
its independent role, even after considering other related types of capital in econometric models. Considering the simultaneous significance of the coefficients of physical and natural capital, in addition to the theoretical criticisms made by researchers empirically, the assumption of the replacement of physical and natural capitals can be seriously considered in theory. As noted in the text, this idea has been quantitatively explored using the proposed econometric model for the first time. Therefore, it is not possible to compare the estimated coefficients with similar studies. The main finding of the present development research is that any other form of capital can not replace natural capital in achieving sustainability. For this purpose, the significance of the estimated coefficient has been used in various econometric models. The results obtained in this respect are consistent with the results of other studies. In addition, the political recommendation of this article is also based on.

The irreplaceable role of natural capital is consistent. Although the use of cross-sectional data, the multiplicity of variables and the multiplicity of their collection sources, and consequently the variety of sampling and differences in aggregation methods, make the article's data somewhat challenging. Still, the researcher tries various alternatives for different types of capital to overcome this unwanted and imposed caste as much as possible and show that the results obtained are sufficiently stable. Finally, it can be concluded that physical capital has the greatest role (the greatest coefficient) in explaining sustainability indicators, but this issue can not play the role of natural capital in the development process. Natural capital, independent of physical capital, affects the indicators of sustainable development. Most environmental economists believe that poor sustainability will lead to the depletion of natural resources and environmental capital. To realize this theory, the concept of strong sustainability and its policy requirements and consequences must first be precisely explained; this issue has also attracted the attention of many environmental economists at the international level. Second, efforts should critique the adverse environmental consequences of policymakers' adherence to poor sustainability. In addition, many of the key variables used have recently been introduced in the environmental economics literature and have not been collected for a long time. It will not be far-fetched if, in the not-too-distant future, with access to more consistent, high-quality data, more sophisticated econometric models can be proposed for the empirical purposes of this paper.

Supplementary Materials: the data and material can be available through an official request from the corresponding author.

Author Contributions: "Conceptualization, NN and NN; methodology, NN; software, NN; validation, NN and MF; formal analysis, NN; investigation, MF; resources, MF; data curation, NN; writing - original draft preparation, $\mathrm{NN}$; writing - review and editing, MF; visualization, NN; supervision, NN; project administration, MF. All authors have read and agreed to the published version of the manuscript."

Funding: "This research received no external funding."

Data Availability Statement: Data will be available by an official request from the corresponding author.

Acknowledgments: Author Thanks kind supports of the Amirkabir university of technology.

Conflicts of Interest: "The authors declare no conflict of interest."

\section{Appendix A}

Study countries: Argentina, Germany, Albania, South Africa, USA, Austria, Jordan, Uruguay, Spain, Australia, Estonia, Algeria, El Salvador, Indonesia, Ireland, Italy, respectively. Pakistan, Portugal, Peru, Turkey, Dominican Republic, China, Denmark, Israel, Russia, Romania, Zimbabwe, Japan, Singapore, Sweden, Switzerland, Chile, France, Finland, Philippines, Southern Canada, Canada, Cambodia, Canada Lithuania, Hungary, 
Morocco, Egypt, Mexico, Moldova, Norway, Nigeria, New Zealand, Venezuela, Netherlands, India, Greece.

\section{References}

[1] Neumayer, E. Weak Versus Strong Sustainability: Exploring the Limits of Two Opposing Paradigms; Edward Elgar Publishing: Cheltenham, UK, 2010.

[2] Solow, R.M. Intergenerational equity and exhaustible resources. Rev. Econ. Stud. 1974, 41, 29-45.

[3] Hartwick, J.M. Intergenerational equity and the investing of rents from exhaustible resources. Am. Econ. Rev. 1977, 67, 972-974.

[4] Neumayer, E. Global warming: Discounting is not the issue, but substitutability is. Energy Policy 1999, 27, 33-43.

[5] Beckerman, W. 'Sustainable development': Is it a useful concept? Environ. Values 1994, 3, 191-209.

[6] Pearce, D.W.; Atkinson, G.D. Capital theory and the measurement of sustainable development: An indicator of "weak" sustainability. Ecol. Econ. 1993, 8, 103-108.

[7] Solow, R. An Almost Practical Step Toward Sustainability; RFF Press: New York, NY, USA, 2014; pp. 11-28.

[8] Martínez-Alier, J.; Munda, G.; O'Neill, J. Weak comparability of values as a foundation for ecological economics. Ecol. Econ. $1998,26,277-286$.

[9] Howarth, R.B. Sustainability as opportunity. Land Econ. 1997, 73, 569-579.

[10] Daly, H.E. Steady-state economics: Concepts, questions, policies. Gaia Ecol. Perspect. Sci. Soc. 1992, 1, 333-338.

[11] Daly, H.E. Toward some operational principles of sustainable development. Ecol. Econ. 1990, 2, 1-6.

[12] Daly, H.E.; Cobb, J.B. For the Common Good; Beacon Press: Boston, MA, USA, 1994.

[13] Costanza, R.; Daly, H.E. Natural capital and sustainable development. Conserv. Biol. 1992, 6, 37-46.

[14] Pelenc, J.; Ballet, J. Strong sustainability, critical natural capital and the capability approach. Ecol. Econ. 2015, 112, 36-44.

[15] Ekins, P.; Simon, S.; Deutsch, L.; Folke, C.; De Groot, R. A framework for the practical application of the concepts of critical natural capital and strong sustainability. Ecol. Econ. 2003, 44, 165-185.

[16] Barbier, E.B.; Burgess, J.C.; Folke, C. Paradise Lost?: The Ecological Economics of Biodiversity; Routledge: New Yor, NY, USA, 2019.

[17] Butchart, S.H.; Walpole, M.; Collen, B.; Van Strien, A.; Scharlemann, JP; Almond, R.E.; Baillie, J.E.; Bomhard, B.; Brown, C.; Bruno, J.; et al. Global biodiversity: Indicators of recent declines. Science 2010, 328, 1164-1168.

[18] Rockström, J.; Steffen, W.; Noone, K.; Persson, Å.; Chapin III, F.S.; Lambin, E.F.; Lenton, T.M.; Scheffer, M.; Folke, C.; Schellnhuber, H.J. A safe operating space for humanity. Nature 2009, 461, 472.

[19] Brand, F. Critical natural capital revisited: Ecological resilience and sustainable development. Ecol. Econ. 2009, 68, 605-612.

[20] Garmendia, E.; Prellezo, R.; Murillas, A.; Escapa, M.; Gallastegui, M. Weak and strong sustainability assessment in fisheries. Ecol. Econ. 2010, 70, 96-106.

[21] Dalmas, L.; Geronimi, V.; Noël, J.; Sang, J.T.K. Economic evaluation of urban heritage: An inclusive approach under a sustainability perspective. J. Cult. Herit. 2015, 16, 681-687.

[22] Janeiro, L.; Patel, M.K. Choosing sustainable technologies. Implications of the underlying sustainability paradigm in the decision-making process. J. Clean. Prod. 2015, 105, 438-446.

[23] Rosén, L.; Back, P.; Söderqvist, T.; Norrman, J.; Brinkhoff, P.; Norberg, T.; Volchko, Y.; Norin, M.; Bergknut, M.; Döberl, G. SCORE: A novel multi-criteria decision analysis approach to assessing the sustainability of contaminated land remediation. Sci. Total Environ. 2015, 511, 621-638.

[24] De Mare, G.; Granata, M.F.; Nesticò, A. Weak and strong compensation for the prioritization of public investments: Multidimensional analysis for pools. Sustainability 2015, 7, 16022-16038.

[25] West, PC Redesigning planning, governance, and policies to achieve multiple sustainable development goals. One Earth 2019, 1, 303-304.

[26] Cerreta, M.; Monno, V. Making Strategies in Spatial Planning: Knowledge and Values; Springer Science \& Business Media: London, UK, 2010; Volume 9.

[27] Garmendia, E.; Gamboa, G. Weighting social preferences in participatory multi-criteria evaluations: A case study on sustainable natural resource management. Ecol. Econ. 2012, 84, 110-120.

[28] Prato, T. Evaluating land use plans under uncertainty. Land Use Policy 2007, 24, 165-174.

[29] Lamorgese, L.; Geneletti, D. Sustainability principles in strategic environmental assessment: A framework for analysis and examples from Italian urban planning. Environ. Impact Assess. Rev. 2013, 42, 116-126.

[30] Aubry, C.; Ramamonjisoa, J.; Dabat, M.; Rakotoarisoa, J.; Rakotondraibe, J.; Rabeharisoa, L. Urban agriculture and land use in cities: An approach with the multi-functionality and sustainability concepts in the case of Antananarivo (Madagascar). Land Use Policy 2012, 29, 429-439.

[31] Jonsson, B.G.; Svensson, J.; Mikusiński, G.; Manton, M.; Angelstam, P. European Union's last intact forest landscapes are at a value chain crossroad between multiple use and intensified wood production. Forests 2019, 10, 564.

[32] Pinto-Correia, T.; Guiomar, N.; Guerra, C.A.; Carvalho-Ribeiro, S. Assessing the ability of rural areas to fulfil multiple societal demands. Land Use Policy 2016, 53, 86-96. 
[33] Rounsevell, M.; Ewert, F.; Reginster, I.; Leemans, R.; Carter, T. Future scenarios of European agricultural land use: II. Projecting changes in cropland and grassland. Agric. Ecosyst. Environ. 2005, 107, 117-135.

[34] Munroe, D.K.; Van Berkel, D.B.; Verburg, P.H.; Olson, J.L. Alternative trajectories of land abandonment: Causes, consequences and research challenges. Curr. Opin. Environ. Sustain. 2013, 5, 471-476.

[35] Verburg, P.H.; Overmars, KP Combining top-down and bottom-up dynamics in land use modeling: Exploring the future of abandoned farmlands in Europe with the Dyna-CLUE model. Lands. Ecol. 2009, 24, 1167.

[36] De Groot, R.S.; Wilson, M.A.; Boumans, R.M. A typology for the classification, description and valuation of ecosystem functions, goods and services. Ecol. Econ. 2002, 41, 393-408.

[37] Schulp, C.J.; Nabuurs, G.; Verburg, P.H. Future carbon sequestration in Europe-Effects of land use change. Agric. Ecosyst. Environ. 2008, 127, 251-264.

[38] Pimm, SL; Raven, P. Biodiversity: Extinction by numbers. Nature 2000, 403, 843.

[39] Portela, R.; Rademacher, I. A dynamic model of patterns of deforestation and their effect on the ability of the Brazilian Amazonia to provide ecosystem services. Ecol. Model. 2001, 143, 115-146.

[40] Schroter, D.; Cramer, W.; Leemans, R.; Prentice, I.C.; Araujo, M.B.; Arnell, N.W.; Bondeau, A.; Bugmann, H.; Carter, T.R.; Gracia, C.A.; et al. Ecosystem service supply and vulnerability to global change in Europe. Science 2005, 310, 1333-1337.

[41] Rounsevell, M.D.; Pedroli, B.; Erb, K.; Gramberger, M.; Busck, A.G.; Haberl, H.; Kristensen, S.; Kuemmerle, T.; Lavorel, S.; Lindner, M. Challenges for land system science. Land Use Policy 2012, 29, 899-910.

[42] Crossman, N.D.; Bryan, B.A.; De Groot, R.S.; Lin, Y.; Minang, P.A. Land science contributions to ecosystem services. Curr. Opin. Environ. Sustain. 2013, 5, 509-514.

[43] Baumgartner, R.J. Sustainable development goals and the forest sector-A complex relationship. Forests 2019, 10, 152.

[44] Ezquerro, M.; Pardos, M.; Diaz-Balteiro, L. Sustainability in forest management revisited using multi-criteria decision-making techniques. Sustainability 2019, 11, 3645.

[45] Seppelt, R.; Lautenbach, S.; Volk, M. Identifying trade-offs between ecosystem services, land use, and biodiversity: A plea for combining scenario analysis and optimization on different spatial scales. Curr. Opin. Environ. Sustain. $2013,5,458-463$.

[46] Pearson, L.J.; Park, S.; Harman, B.; Heyenga, S. Sustainable land use scenario framework: Framework and outcomes from peri-urban South-East Queensland, Australia. Landsc. Urban Plann. 2010, 96, 88-97.

[47] Munda, G.; Nijkamp, P.; Rietveld, P. Qualitative multicriteria methods for fuzzy evaluation problems: An illustration of economic-ecological evaluation. Eur. J. Oper. Res. 1995, 82, 79-97.

[48] Munda, G. Social Multi-Criteria Evaluation for a Sustainable Economy; Springer: Heilderberg, Germany, 2008 ; Volume 17.

[49] Langemeyer, J.; Gómez-Baggethun, E.; Haase, D.; Scheuer, S.; Elmqvist, T. Bridging the gap between ecosystem service assessments and land-use planning through Multi-Criteria Decision Analysis (MCDA). Environ. Sci. Policy 2016, 62, 45-56.

[50] Gamper, CD; Turcanu, C. On the governmental use of multi-criteria analysis. Ecol. Econ. 2007, 62, $298-307$.

[51] Jeffreys, I. The use of compensatory and non-compensatory multi-criteria analysis for small-scale forestry. Small Scale For. Econ. Manag. Policy 2004, 3, 99-117.

[52] Oikonomou, V.; Dimitrakopoulos, P.G.; Troumbis, A.Y. Incorporating ecosystem function concept in environmental planning and decision making by means of multi-criteria evaluation: The case-study of Kalloni, Lesbos, Greece. Environ. Manag. 2011, 47, 77-92.

[53] Bagheri, M.; Sulaiman, W.; Vaghefi, N. Land use suitability analysis using multi criteria decision analysis method for coastal management and planning: A case study of Malaysia. J. Environ. Sci. Technol. 2012, 5, 364-372.

[54] Singh, S.J.; Smetschka, B.; Grima, N.; Ringhofer, L.; Petridis, P.; Biely, K. Social multi-criteria evaluation (SMCE) in theory and practice: Introducing the software OPTamos. Soc. Ecol. Work. Pap. 2016, 160, 1-91.

[55] Etxano, I.; Garmendia, E.; Pascual, U.; Hoyos, D.; Díez, M.; Cadiñanos, J.A.; Lozano, P.J. A participatory integrated assessment approach for Natura 2000 network sites. Environ. Plan. C Gov. Policy 2015, 33, 1207-1232.

[56] Etxano, I.; Barinaga-Rementeria Zabaleta, I.; García Alonso, O. Conflicting values in rural planning: A multifunctionality approach through social multi-criteria evaluation. Sustainability 2018, 10, 1431.

[57] Munda, G. Social multi-criteria evaluation: Methodological foundations and operational consequences. Eur. J. Oper. Res. $2004,158,662-677$.

[58] Funtowicz, S.O.; Ravetz, J.R. The worth of a songbird: Ecological economics as a post-normal science. Ecol. Econ. 1994, 10, 197-207.

[59] O'Neill, J. Representing people, representing nature, representing the world. Environ. Plan. C Gov. Policy 2001, 19, 483500.

[60] Greco, S.; Figueira, J.; Ehrgott, M. Multiple Criteria Decision Analysis; Springer: New York, NY, USA, 2016.

[61] Munda, G. Multicriteria Evaluation in a Fuzzy Environment: Theory and Applications in Ecological Economics; PhysicaVerlag: Heidelberg, Germany, 1995.

[62] Joint Research Centre of the European Commission. NAIADE: Manual and Tutorial; Joint Research Centre: Istra, Italy, 1996.

[63] Acosta, M.; Corral, S. Participatory multi-criteria assessment of forest planning policies in conflicting situations: The case of Tenerife. Forests 2015, 6, 3946-3969.

[64] Iojă, I.; Hossu, C.; Niţă, M.; Onose, D.; Badiu, D.; Manolache, S. Indicators for environmental conflict monitoring in Natura 2000 sites. Proc. Environ. Sci. 2016, 32, 4-11. 
[65] Ruiz Urrestarazu, E.; Galdos-Urrutia, R. La perdida de los espacios agrarios y la artificialización del suelo y forestacion en España y en el Pais Vasco. Lurralde Investig. Espac. 2013, 36, 121-133.

[66] Cavallaro, F.; Ciraolo, L. A multicriteria approach to evaluate wind energy plants on an Italian island. Energy Policy 2005, 33, 235-244.

[67] Benetto, E.; Dujet, C.; Rousseaux, P. Integrating fuzzy multicriteria analysis and uncertainty evaluation in life cycle assessment. Environ. Model. Softw. 2008, 23, 1461-1467.

[68] Shmelev, S.E.; Rodríguez-Labajos, B. Dynamic multidimensional assessment of sustainability at the macro level: The case of Austria. Ecol. Econ. 2009, 68, 2560-2573.

[69] Monterroso, I.; Binimelis, R.; Rodríguez-Labajos, B. New methods for the analysis of invasion processes: Multi-criteria evaluation of the invasion of Hydrilla verticillata in Guatemala. J. Environ. Manag. 2011, 92, 494-507.

[70] Kolinjivadi, V.; Gamboa, G.; Adamowski, J.; Kosoy, N. Capabilities as justice: Analysing the acceptability of payments for ecosystem services (PES) through 'social multi-criteria evaluation'. Ecol. Econ. 2015, 118, 99-113.

[71] Vallejo, M.C.; Burbano, R.; Falconí, F.; Larrea, C. Leaving oil underground in Ecuador: The Yasuní-ITT initiative from a multi-criteria perspective. Ecol. Econ. 2015, 109, 175-185.

[72] Tarrason, D.; Ortiz, O.; Alcaniz, J.M. A multi-criteria evaluation of organic amendments used to transform an unproductive shrubland into a Mediterranean dehesa. J. Environ. Manag. 2007, 82, 446-456.

[73] Russi, D. Social Multicriteria Evaluation and Reneweable Energy Policies. Ph.D. Thesis, Universidad de Barcelona, Bellaterra, Spain, 2007. 